\title{
PELAKSANAAN PROGRAM PARENTING DI PAUD TERPADU YAYASAN PUTRA PUTRI GODEAN, SLEMAN, DAERAH ISTIMEWA YOGYAKARTA
}

\author{
IMPLEMENTATION OF PARENTING PROGRAM IN THE INTEGRATED PAUD \\ YAYASAN PUTRA PUTRI GODEAN, SLEMAN, SPECIAL AREA YOGYAKARTA
}

Oleh Kholisatul Nurjanah, Pendidikan Luar Sekolah

\begin{abstract}
ABSTRAK
Penelitian ini bertujuan untuk mendeskripsikan: 1) pelaksanaan program parenting, 2) faktor pendukung pelaksanaan program parenting 3) faktor apakah yang menghambat pelaksanaan program parenting yang ada di Paud Terpadu Yayasan Putra Putri Godean. Penelitian ini menggunakan pendekatan deskriptif kualitatif dengan metode studi kasus, dan mengambil lokasi di Jalan Sokonilo, godean, Sleman, Yogyakarta. Subyek dalam penelitian ini adalah Pendidik, tenaga kependidikan dan orangtua siswa Paud terpadu yayasan putra putri godean. Pengumpulan data menggunakan metode observasi, wawancara, dan dokumentasi. Peneliti merupakan instrumen utama dalam melakukan penelitian, yang dibantu dengan pedoman observasi, dokumentasi, dan wawancara. Teknik yang digunakan dalam melakukan analisis data adalah reduksi data, penyajian data, dan pengambilan kesimpulan.Keabsahan data yang dilakukan untuk menjelaskan data dengan menggunakan triangulasi sumber. Hasil penelitian menunjukkan bahwa: 1) Proses pelaksanaan program parenting dibagi menjadi dua kelompok yaitu program terencana yang terdiri dari pojok gizi dan kelas parenting, sementara program insidental yaitu konsultasi orangtua dan kunjungan rumah. 2) Faktor pendukung Faktor internal antara lain komitmen pendidik dan tenaga kependidikan dalam menjalakan program didukung dengan tersedianya sarana dan prasarana yang memadai serta turut aktifnya orangtua. 3) Faktor penghambat untuk kelas parenting yaitu waktu pelaksanaan yang belum pasti, sehingga sering terjadi kemunduran dari target semula dan kekurangan SDM.
\end{abstract}

Kata kunci: program parenting, Paud Putra Putri Godean.

\begin{abstract}
This study aimed to describe: 1) Parental education program implementation or parenting, 2) factor supporting implementation of educational programs parenthood or parenting, 3) whether the factors that hinder the implementation of parental education or parenting program in early childhood Integrated Yayasan Putra Putri Godean. This study used a qualitative descriptive approach, and take a place in Jalan Sokonilo, godean, Sleman, Yogyakarta. Subjects in this study were educators, staff and parents of integrated early childhood foundation godean sons and daughters. Collecting data using the method of observation, interviews, and documentation. The researcher is the main instrument in conducting research, assisted with the guidelines for observation, documentation, and interviews. Techniques used in analyzing the data is the data reduction, data presentation, and making conclusions. The validity of the data that is made to explain the data using triangulation sources The results showed that: 1) The process of implementation of parental education are divided into two groups: a planned program consisting of a corner of nutrition and parenting classes, while the incidental program is consulting parents and home visits. 2) The supporting factors Internal factors such as the seriousness of the teachers and the run the program supported by the availability of adequate facilities and infrastructure as well as active co-parents. 3) inhibiting factors, namely for parenting classes that implementation time is uncertain and only a month range that is used as a reference to make frequent setbacks from the original target and the lack of human resources
\end{abstract}

Keywords: parental education, Paud Putra Putri Godean 


\section{Diklus: Jurnal Pendidikan Luar Sekolah, 1(1), Maret 2017 - 41 \\ Kholisatul Nurjanah}

\section{PENDAHULUAN}

Kehidupan dan perkembangan manusia tidak lepas dari pendidikan. Hal itu sesuai dengan pengertian pendidikan yang tercantum dalam sistem pendidikan nasional yang berbunyi "Pendidikan adalah usaha sadar dan terencana untuk mewujudkan suasana belajar dan proses pembelajaran agar peserta didik secara aktif mengembangkan potensi dirinya untuk memiliki kekuatan spiritual keagamaan, pengendalian diri, kepribadian, kecerdasan, akhlak mulia, serta keterampilan yang diperlukan dirinya, masyarakat, bangsa dan negara." Jalur pendidikan terdiri atas pendidikan formal, nonformal, dan informal. Ketiga jalur pendidikan tersebut dapat saling melengkapi dan memperkaya. (UU RI No. 20 Tahun 2003 tentang Sistem Pendidikan Nasional, pasal 1 dan 13)

\section{Pendidikan Anak Usia Dini} (PAUD) yang dikembangkan di Kabupaten Sleman untuk mempersiapkan anak masuk ke jenjang pendidikan dasar selalu meningkat dari tahun ke tahun. Pada tahun 2011, terdapat play group (kelompok bermain) sebanyak 219 lembaga dengan jumlah siswa 6.755 anak dan 1046 pamong belajar, Taman Penitipan Anak (TPA) 107 lembaga dengan jumlah anak yang dititipkan 2.739 anak dengan pamong belajar sebanyak 516 orang. Dengan jumlah PAUD di Kabupaten Sleman menunjukan bahwa pihak pemerintah serius dalam menangani dan melayani pendidikan untuk anak usia dini. Salah satu tujuannya adalah untuk mengoptimalkan pertumbuhan dan perkembangan anak sesuai dengan tahap perkembangannya.

Pendidikan untuk anak usia dini perlu penting, maka adanya dukungan dari orangtua dalam mengoptimalkan pertumbuhan, perkembangan dan potensi pada diri anak. Peran orangtua dalam mensukseskan pertumbuhan, perkembangan dan potensi anak dapat diwujudkan salah satunya adalah dengan menjukan betuk dukungan dalam proses pembelajaran. Proses pembelajaran erat kaitannya dengan berhasil atau tidaknya nilai - nilai yang ditanamkan kepada diri anak baik disekolah maupun dirumah. Menurut Hibana dalam Partini (2010: 56), Tugas pendidik disekolah tidaklah mengambil alih pendidikan dalam keluarga melainkan membantu orangtua untuk mengembangkan potensi anak. Pendidik utama untuk anak usia dini tetaplah kedua orangtua dalam keluarga. Maka dari itu orangtua perlu paham kebtuhan pendidikan anak - anaknya sesuai dengan umur dan tingkat perkembanganSalah satu bagian terpenting dalam komponen masyarakat Indonesia adalah anak. Pendidikan dari orang tua kepada anak tidak hanya terapkan di dalam rumah tapi juga disekolah sebgaibentuk dukungan kegiatan belajar mengajar. Menurut Yasin Musthofa (2007:53), Pendidikan dalam keluarga 


\section{Diklus: Jurnal Pendidikan Luar Sekolah, 1(1), Maret 2017 - 42 Kholisatul Nurjanah}

mempunyai makna Keluarga dan anak adalah: keluarga dijadikan sebagai lembaga pendidikan yang diselengarakan dan ditanggani langsung oleh kedua orang tua untuk menumbuhkan kemampuan dasar berupa emosi terhadap anak, masa kanak kanak awal atau antara usia 2-6 tahun agar sang anak dalam tingkah lakunya secara dewasa nanti, akan atau dapat mencerminkan sikap yang menjadi ciri dari kecerdasan emosi, yakni pengendalian diri dan empati. Kecerdasan emosi dan pengendalian diri merupakan nilai - nilai yang bisa ditanamkan dalam keluarga. Banyak aspek dan nilai nilai lain yang bisa kita tanamkan kepada anak dalam pendidikan keluarga.

Maka dari itu Pendidikan bagi orangtua penting dilakukan untuk memenuhi kebutuhan dalam mendidik anak maka munculah konsep pendidikan orang dewasa. Menurut Suprijanto (2005:11) Pendidikan orang dewsa andragogy berbeda dengan pendidikan anak - anak atau pedagogy. Pendidikan anak - anak berlangsung dalam bentuk identifikasi dan peniruan, sedangkan pendidikan orang dewasa berlangsung dalam bentuk pengarahan diri sendiri untuk memecahkan masalah.

Berdasarkan penjabaran diatas maka dapat ditarik kesimpulan bahwa pendidikan orang dewasa dan pola asuh (pengasuhan) sangat erat kaitannya. Banyak program pendidikan keorangtuaan yang berjalan dengan dinamika yang cukup tinggi baik secara formal maupun non formal. Salah satu program dalam pendidikan Keorangtuaan adalah program parenting yang umumnya dilakukan oleh suatu lebaga sekolah, baik SMA, SMP, SD maupun PAUD. Pola asuh atau parenting disini adalah pendidikan keorangtuaan yang diterapkan lembaga untuk memenuhi kebutuhan pendidikan. Pendidikan tidak hanya untuk peserta didik namun juga untuk orangtua dari peserta didik. Sehingga diharapkan terbentuk keselarasan antara pendidikan yang anak peroleh disekolah dengan pendidikan yang orangtua terapkan dirumah.

Konsep program parenting adalah memadukan pendidikan yang diperoleh anak disekolah dengan dirumah. Hal seharusnya menjadi perhatian, untamanya untuk penyelenggara pendidikan anak usia dini. Sebagai lembaga pendidikan anak usia dini seharusnya menfasilitasi lebih jauh untuk pendidikan keorangtuaan atau parenting. Kegiatan ini dimaksudkan agar orangtua mampu menjalankan tugasnya sebagai pendidik utama bagi anak dan selaras dengan pendidikan yang diterima anak di sekolah.

Selaras dengan pernyataan diatas mengenai pengertian pentingnya pendidikan keorangtuaan atau parenting maka yayasan putra - putri godean mewadahi orangtua murid paud terpadu dalam kegitan parenting yang dilakukan sebulan dua kali dengan agenda yang berbeda. Parenting atau wadah komunikasi 


\section{Diklus: Jurnal Pendidikan Luar Sekolah, 1(1), Maret 2017 - 43 \\ Kholisatul Nurjanah}

merupakan usaha dari lembaga bagi orangtua untuk saling berbagi informasi dan pengetahuan tentang bagaimana melaksanakan pendidikan anak usia 0-6 tahun dirumah. Perenting yang dilaksanakan oleh Yasayan Putra Putri Godean telah berjalan secara keberlanjutan.

Kondisi dari program parenting yang dilaksanakan yayasan putra putri godean adalah dengan adanya pertemuan disetiap bulan. Pertemuan pertama adalah inisiatif dari yayasan sendiri sebagai wadah shering atau tukar pendapat dengan mendatangkan para ahli dibidangnya sebagai pemateri kemudian dilanjutkan dengan diskusi antara pengelola dengan orangtua murid mengenai bentuk kegiatan dan perkembangan kemampuan anak anak. Pada pekan kedua adalah inisiatif dari orangtua murid yang menginginkan adanya program tambahan untuk menjalin keakraban antara pengelola, guru dan antar orangtua wali itu sendiri, salah satu bentuk kegiatan yaitu senam bersama diahir pekan yang diahiri dengan sharing antar orangtua murid, pendidik dan pengelola. Yayasan dan orangtua mempunyai program bersama yang diberinama pojok gizi dimna orengtua murid dibagi menjadi kelompok kelompok kecil untuk menyiapkan makan siang putra putri setiap hari jum'at di sekolah. Berkaca dari kegitan parenting yang diterapkan di yayasan putra putri godean layaknya semua lembaga pendidikan anak usia dini khususnya yang ada di daerah istimewa yogyakarta menerapkan pula pendidikan keorangtuaan atau parenting. Namun, untuk saat ini masih sedikit lembaga pendidikan khususnya anak usia dini yang menfasilitasi pendidikan keorangtuan atau parenting. Belum semua lembaga dapat menjalankan program parenting secara berkelanjutan. Sehingga program parenting yang ada di lingkungan pendidikan masyarakat saat ini belum belum optimal.

Berdasarkan latar belakang ditas maka peneliti tertarik untuk meneliti bagaimana pelaksanaan pendidikan keorangtuaan atau parenting yang ada di Pendidikan orang dewsa andragogy berbeda dengan pendidikan anak - anak atau pedagogy. Pendidikan anak - anak berlangsung dalam bentuk identifikasi dan peniruan, sedangkan pendidikan orang dewasa berlangsung dalam bentuk pengarahan diri sendiri untuk memecahkan masalah.

Berdasarkan penjabaran diatas maka dapat ditarik kesimpulan bahwa pendidikan orang dewasa dan pola asuh (pengasuhan) sangat erat kaitannya. Banyak program pendidikan keorangtuaan yang berjalan dengan dinamika yang cukup tinggi baik secara formal maupun non formal. Salah satu program dalam pendidikan Keorangtuaan adalah program parenting yang umumnya dilakukan oleh suatu lebaga sekolah, baik SMA, SMP, SD maupun PAUD. Pola asuh atau parenting disini adalah pendidikan keorangtuaan yang diterapkan lembaga untuk memenuhi 


\section{Diklus: Jurnal Pendidikan Luar Sekolah, 1(1), Maret 2017 - 44 \\ Kholisatul Nurjanah}

kebutuhan pendidikan. Pendidikan tidak hanya untuk peserta didik namun juga untuk orangtua dari peserta didik.

\section{METODE PENELITIAN}

\section{Jenis Penelitian}

Penelitian ini merupakan penelitian deskriptif dengan pendekatan kualitatif karena bermaksud untuk mendeskripsikan, menguraikan dan menggambarkan bagaimana Pelaksanaan Parenting Di Paud Terpadu Yayasan Putra Putri Godean, Sleman, Daerah Istimewa Yogyakarta. Mulai dari perencanaan, jenis kegitan keorangtuaan, pelaksanaan, faktor pendukung dan penghambat, hingga evaluasi program pendidikan keorangtuaan yang ada di Paud Terpadu Yayasan Putra Putri Godean.

\section{Penentuan Subjek dan Objek Penelitian}

Menurut Suharsimi Arikunto (2002: 109) yang dimaksud subjek penelitian adalah benda, hal atau tempat data untuk variabel penelitian yang dipermasalahkan. Dari definisi ini dapat disimpukan bahwa yang dimaksud subyek adalah pelau pokok pembicaraan yang menjadi permaslahan dan dipakai untuk percobaan. Penentuan subyek dalam penelitian ini adalah untuk mengumpuklan banyak informasi dari berbagai sumber.

Moleong

(2005:

mengungkapkan sumber data atau nara sumber (informan) bisa berupa orang, dokumentasi (arsip), atau berupa kegiatan. Dalam menentukan subyek penelitian peneliti mengunakan teknik sampling. Sampling yang dimaksud disini adalah untuk menjaring sebanyak mungkin informasi dari berbagai sumber.

Berdasarkan pengertian ditas maka subyek penelitian adalah pendidik, tenaga kependidikan, dan orangtua peserta didik. Sementara obyek penelitian meliputi kegitan pendiikan keorangtuaan (parenting) di paud terpdu putra puti godean.

\section{Waktu dan Tempat Penelitian}

Penelitian ini dilaksanakan di i Paud Terpadu Yayasan Putra Putri Godean. yang beralamatkan di JL. Sokonilo, Godean, Sleman, Daerah Istimewa Yogyakarta. Waktu penelitian dimulai dari bulan Oktober - Desember.

\section{Prosedur Penelitian}

Menurut Sugiyono (2012:61) dalam penelitian kualitatif instrument utamanya adalah peneliti sendiri, namun selanjutnya setelah fokus penelitian menjadi jelas, maka kemungkinan akan dikembangkan instrument penelitian sederhana, yang diharapkan dapat melengkapi data dan membandingkan dengan data yang telah ditentukan melalui observasi dan wawancara. Data-data yang dibutuhkan oleh peneliti akan digali dengan menggunakan metode pengumpulan data observasi, wawancara, dan dokumentasi. 
kesimpulan

\section{HASIL PENELITIAN DAN \\ PEMBAHASAN}

Hasil penelitian dan pembahasan

\section{Instrumen dan Teknik Pengumpulan} Data

Instrumen penelitian adalah alat pengumpulan data (Moleong 2010: 168). Melalui istrumen, peneliti mengumpulkandata yang berkaitan dengan masalah penelitian. Menurut Sugiono (2009: 59), terdapat dua hal yang mempengaruhi kualitas data hasil penelitian, yitu kualitas istrumen penelitian dan kualitas pengumpulan data. Dalam penelitian kulitatif yang menjadi instrumen atau alat peneliti adalah peneliti itu sendiri. Dengan dibantu dengan menggunakan pedoman sederhana untuk mengumpulkan data sesuai dengan masalah yang akan diteliti. Pedoman yang digunakan adalah pedoman observasi, pedoman wawancara, pedoman dokumentasi.

\section{Teknik Analisis Data}

Dalam penelitian ini teknik analisis yang digunakan adalah kualitatif deskriptif. Data yang dikumpulkan digolongkan menjadi dua jenis yaitu data utama dan data pendukung. Data utama berupa orang orang yang terlibat langsung dalam kegiatan penelitian, sedangkan data pendukung berupa foto dan catatan catatan. Lofland dalam (Moelong, 2001: 112). Menurut sugiono (2009: 92), analisis data terbagi menjadi tiga tahapan yaitu: reduksi data, penyajian data, dan penarikan penelitian mengenai Pelaksanaan

Pendidikan Keorangtuaan Parenting Di Paud Terpadu Yayasan Putra Putri Godean, Sleman, Daerah Istimewa Yogyakarta yaitu:

Hasil Penelitian

1. Tahapan pelaksanaan program parenting yang ada di Paud Terpadu Yayasan Putra Putri Godean. Ada empat kegitan keorangtuuan di di puad terpadu putra puri godean, kemudian dikelompokan menjadi dua jenis yaitu program terencana dan insidental. Program terencana meliputi kelas parenting dan pojok gizi sementara program insidental berupa kunjungan rumah dan konsultasi orangtua. Dari keempat kegiatan keorangtuaan yang dilaksanakan di PAUD Terpadu Putra Putri Godean pojok gizi merupakan satu satunya kegiatan yang melibatkan semua elemen dalam pendididkan keorangtuaan secara bersamaan dalam pelaksanaanya yaitu orangtua, pendidik dan peserta didik. Berbeda dengan pojok gizi, untuk kegiatan parenting bertema yang dilakukan 1-2 bulan sekali memerlukan perencanaan yang matang karena melibatkan banyak pihak. Berikut rincian pelaksanaan program Parenting bertema yang 


\section{Diklus: Jurnal Pendidikan Luar Sekolah, 1(1), Maret 2017 - 46 \\ Kholisatul Nurjanah}

dilaksanakan di PAUD Terpadu Putra

Putri Godean dalam perencanaan ada beberapa aspek penting yang harus ditentukan dan didiskusikan dengan orangtua yaitu: Menentukan waktu pelaksanaan, menentukan tema parenting, menentukan narasumber. Pelaksanaan kegitan umumnya berjalan dengan lanjar didukung dengan sumberdaya manusia (pendidik, orangtua) dan ketersidiaan sarana dan prasarana di sekolah. Bentuk evaluasi yang dirumuskan yang oleh pihak sekolah dalam melihat berhasil atau tidaknya pendidikan keorangtuaan yang dilaksanakan dapat dievaluasi melalui internal dan eksternal sekolah. Diantaranya terdiri dari beberapa penilaian mengenai: partisipasi orangtua, ketepatan waktu pelaksanaan, pertanyaan yang diajukan warga belajar, dan keseuaian tema dengan kebutuhan warga belajar atau orangtua.

2. Faktor pendukung pelaksanaan program parenting di Paud Terpadu Yayasan Putra Putri Godean yaitu mencakup internal dan eksternal sekolah meliputi: keseriusan dan konsistensi yang ditunjukan oleh lembaga dengan adanya 4 program pendidikan keorangtuaan didukung dengan ketersediaan sarana dan prasarana yang memadai didukung dan kerjasama saling mendukung antara sekolah dan orangtua siswa.
3. Faktor penghambat pelaksanaan program parenting yang ada di Paud Terpadu Yayasan Putra Putri Godean. Dalam 4 kegitan pendidikan keorangtuaan yang sering mengalami hambatan yaitu kelas perenting. Pihak sekolah dan pihak orangtua kesulitan menentukan jadwal pertemuan untuk pelaksanaan program sehingga kegiatan sering molor dari yang direncanakan oleh pihak sekoh sendiri. Namun pihak sekolah berfikiran jika tidak mempertimbangkan dari pihak orangtua, mereka kurang mantap dalam menjalankan program. Mengapa demikian karena yang menjadi pertimbangan utama dalah kehadiran dari orangtua peserta didik, sehingga kegiatan yang telah direncanakan dan ilmu ataupun pengalam yang dibagi oleh pemateri dapat tersampaikan kepada orangtua peserta didik. Uaya mengatasi hambatan pelaksanaan program pendidikan keorangtuaan atau parenting yang ada di Paud Terpadu Yayasan Putra Putri Godean? Sejauh ini belum ada usaha nyata yang dilakukan pihak sekoalah untuk menangani hal tersebut. Karena fokus utama mereka masih pada kehadiran orangtua peserta didik, mengingat tujuan mereka adalah kebermanfaatkan dari program bisa dirasakan oleh semua orangtua peserta didik. Komunikasi menjadi poin utama antara pihak sekolah dan orangtua peserta didik dalam menentukan waktu berlangsungnya program. Saling menghargai waktu

\section{Pembahasan}

Mukhtar Latif (2013: 206) 


\section{Diklus: Jurnal Pendidikan Luar Sekolah, 1(1), Maret 2017 - 47 Kholisatul Nurjanah}

mengungkapkan bahwa pendidikan orangtua (parenting) adalah pendidikan yang diberikan kepada orangtua dalam rangka untuk mengetahui dan mengaplikasikan pendidikan yang tepat dalam mendidik anak usia dini terutama saat anak berada dalam lingkungan keluarga bersama orangtuanya dirumah. Keluarga adalah unit sosial terkecil yang ada di masyarakat. Keluarga terbentuk atas dasar komitment antar suami dan istri dalam mewujudkan fungsi sosial, fungsi pendidikan yang harus benar - benar di optimalkan sebagai mitra dari lemaba penyelengara pendidikan anak usia dini atau sering kita sebut dengan PAUD.

Berikut macam - macam pendidikan keorangtuaan yang di jabarkan oleh Mukhtar Latif (2013: 262) menyatakan bahwa dalam penguatan PAUD berbasis keluarga ada beberapa program yang dapat dikembangkan antara lain: Kelas Pertemuan Orangtua (KPO), Keterlibatan Orang tua di Kelompok Kelas Anak (KOK), Keterlibatan Orang tua dalam Acara Bersama (KODAB), Hari Konsultasi Orang tua (HKO), Kunjungan Rumah. dari lima kegitan yang di jabarkan di atas paud putra putri godean telah melaksanakan empat diantaranya yaitu KPO yang terwujud dalam kelas parenting, KODAB dalam pojok gizi, kunjungan rumah dan konsultasi orangtua.

Berdasarkan hasil penelitian, maka terdapat beberapa pokok pembahasan, yaitu:
1. Tahapan pelaksanaan program parenting Paud Terpadu Yayasan Putra Putri Godean. Anisah basleman

(2011:

mengungkapkan sifat dasar orang dewasa dalam belajar adalah belajar kaitannya dengan tahap perkembangan kedewasaan. Belajar bagi orang dewasa berbasis pada kebutuhan. Jika hal dipelajari dianggap kurang dibutuhkan oleh orang dewasa atau orang tua, maka tidak akan timbul kesadaran untuk mempelajari hal tersebut. Hal ini tercermin dalam proses pelaksanaan mulai dari perencanaan hingga evaluasi yang melibatkan orangtua sehingga mereka bisa memilih sesuai dengan kebutuhan mereka maka orang tua dapat menjalani kegitan tanpa beban. Hal tersebut sesui dengan pernyataan Suprijanto (2005: 57) bahwa dalam perkembangan pendidikan orang dewasa saat ini lebih banyak menguakan metode partisipatif, dimana semua pihak yang terkait dalam pendidikan dilibatkan dalam proses pendidikan mulai dari perencanaan, pelaksanaan, dan evaluasi. Pelaksanaan pendidikan orang dewasa cukup evektif mengunakan metode parsitipatif karena oarang dewasa memiliki pengalaman yang berbeda yang tidak bisa dipukul rata antara satu 


\section{Diklus: Jurnal Pendidikan Luar Sekolah, 1(1), Maret 2017 - 48 \\ Kholisatul Nurjanah}

dan yang lain.

Pada pelaksanaan kegitan kelas parenting contohnya ada tahapan penarikan kesimpulan peserta sendiri yang meumuskan dan dibantu oleh pemateri. Mengingat masing masing - masing peserta memiliki latar belakang pengalaman yang berbeda maka dalam penarikan kesimpulan antara orang satu dan orang yang lain belum tentu sama. Model pembelajaran yang partisipatif menjadikan orangtua lebih leluasa menyampaikan aspirasinya. Hal ini seiring sejalan dengan pendekatan yang digunakan dalam pelatihan adalah partisipatif yang biasanya digunakan dan disebut juga siklus belajar dari pengalaman (Suprijanto, 2007:165).

Orangtua terlibat dari perencanaan hingga evalusi. Evaluasi program terencana maupun program insidental dilakukan secara intensif baik latar belakang kegiatan dan kesesuaian dengan kebutuhan orangtua. Hal tersebut sesui dengan peryataan (Djuju sudjana 2008;107) menganai metode kasus dalam evaluasi yaitu, digunakan untuk mempelajari secara intensif tentang latar belakang keadaan sekarang dan interaksi lingkungan, baik digunakan untuk semua unit sosial seperti individu, kelompok, lembaga, komunitas maupun untuk perisriwa keadaan dan sebagainya.

2. Faktor pendukung pelaksanaan program parenting Paud Terpadu Yayasan Putra Putri Godean. Faktor internal pendukung berjalanya program yaitu sumber daya manusia (SDM) dan ketersediaan sarana prasarana. Pendidik, tenaga kependidikan maupun orang - orang yang masuk dalam struktur kepengurusan Paud Terpadu Yayasan Putra Putri Godean menjadi SDM penggerak setiap program. Program yang telah terencana dapat berjalan dengan baik dengan dukungan sarana prasarana yang memadai disekolah. Kombinasi kedua hal tersebut menjadi pilar dalam pelaksanaan setiap progran pendidikan keorangtuaan di Paud Terpadu Yayasan Putra Putri. Fator eskternal yaitu Dukungan dari orangtua tidak hanya ikut berpartisipasipasi dalam setiap kegiatan namun juga menyumbangkan gagasan dalam perencanaan kegiatan maupun memmperi masukan untuk evaluasi program.

3. Faktor - faktor penghambat pelaksanaan program pendidikan keorangtuaan atau parenting yang ada di Paud Terpadu Yayasan Putra Putri Godean. Keberlangsungan kegiatan selama dua tahun Paud Terpadu Yayasan Putra Putri Godean berdiri masih menggunakan cara yang sama dalam menentukan waktu pelaksanaan 


\section{Diklus: Jurnal Pendidikan Luar Sekolah, 1(1), Maret 2017 - 49 Kholisatul Nurjanah}

kelas parenting. Meskipun banyak yang harus diantisipasi pihak sekolah seperti kekurangan SDM karena sebagian pendidik harus mengikuti seminar atau pelatihan. Namun hal tersebut masih dirasa efektif untuk mengumpulkan orangtua siswa dalam kegiatan.

\section{KESIMPULAN DAN SARAN}

\section{Simpulan}

Berdasarkan uraian dari hasil penelitian dan pembahasan yang telah dilakukan, maka peneliti dapat menarik kesimpulan sebagai berikut:

Proses pelaksanaan program pendidikan keorangtuaan atau parenting yang ada di Paud Terpadu Putra Putri Godean adalah dengan melakukan perencanaan dan mengelompokam menjadi dua jenis program yaitu program terencana dan program insidental. Program terencana yaitu kelas parenting dan pojok gizi, sementara program insidental mencakup kunjungn rumah dan konsultasi orangtua. Dalam perencanaan khususnya untuk program terencana pihak sekolah melibatakn orangtua dalam menyipkan program. Orangtua diwakili oleh koordinator orangtua untuk menjembatani aspirasinya dengan sekolah. Secara keseluruhan mulai dari kapan kegitan akan berlangsung, tema kegitan dan menu untuk kegitan pojok gizi. Berbeda dengan diluar sekolah. Sementara faktor eksternal lembaga dalah kesesuaian tema dengan program terencana, kelompok program insidental lebih pada interent sekolah yang mengamati apakah dibutuhkan untuk melakukan kegitan tersebut. Pada tahap pelaksanaan kelompok program terencana yang berjalan rutin dan sesuai jadwal adalah kegitan pojok gizi yang dilakukan sepekan sekali tiap hari jum'at. Pojok gizi di lakukan selepas kegitan belajar mengajar berlangsung. Orangtua yang memegang kendali dalam kegitan pojok gizi, dan pendidik hanya membatu mengkonsikan anak - anak untuk mengantri. Disini terlihat edukasi berjalan pada semua pihak baik dari orangtua yang belajar adil, anak yang belajar sabar untuk mengntri dan pendidik yang membebaskan orangtua untuk mengatur kegitan.

Kelas parenting terlaksana dua kali pertemuan, secara keseluruhan kegitan berjalan lancar. Hanya saja untuk pertemuan kedua mengalami keterlambatan pelaksanaan karena tanggal tidak ditentukan hanya rentang bulan saja. Untuk kegitan insidental yang terencana adalah konsultasi orangtua. Setiap program dilakukan evalusi, untuk program terencana dilakukan evaluasi internal dan ekternal. Evaluasi internal dari pihak sekolah kurang berani mengmbil keputusan untuk waktu pelaksanaan kegitan kelas parenting sehingga sekolah kekurangan SDM karena harus dibagi dengan pelatihan pendidik

kebutuhan, dan kehadiran orangtua dalam kegitan. Khusus untuk 
program insidental evaluasi yang dilakukan mencakup internal lembaga. Orangtua terlibat dalam perencanaan, pelaksanaan dan evaluasi kegitan. Setiap program di desain sesuai dengan prinsip pendidikan dan pembelajaran orang dewasa.

Faktor pendukung pelaksanaan program pendidikan keorangtuaan atau parenting yang ada di Paud Terpadu Putra Putri Godean dibagi menjadi dua yaitu internal dan eksternal. Faktor internal antara lain keseriusan pendidik dan tenaga kependidikan dalam menjalakan program didukung dengan tersedianya sarana dan prasarana yang memadai. Haltersebut terlihat dari banyaknya kegitan keorangtuaan yang telah dilaksanaan yaitu pojok gizi, kelas parenting, konsultasi orangtua dan kunjungan rumah. faktor ekternal pendukung kegitan adalah sikap aktif orangtua dalam mendukung setiap program yang dilaksanakan sekolah. Orangtua memiliki koordinator untuk menjembati aspirasi anatara sekolah dan orangtua.

Penghambat pelaksanaan program pendidikan keorangtuaan atau parenting yaitu terjadi pada program terencana kelas parenting. Waktu pelaksanaan yang belum pasti dan hanya rentang bulan yang digunakan sebagai acuan menjadikan sering terjadi kemunduran dari target semula. Beberapa waktu pihak sekolah kekurangan SDM karena waktu kegitan berbenturan dengan jadwal diluar seperti pelatihan atau woorkshop bagi pendidik.
Dalam mengatasi hambatan pelaksanaan program pendidikan keorangtuaan atau parenting komunikasi dua arah antara orangtua dengan sekolah. Mengingat pihak sekolah masih mengutamakan kuantitas (keterlibatan dan keharidan orangtua) maka pihak sekolah harus bekerja ekstra ketika ada benturan jadwal.

\section{Saran}

Pihak sekolah sebaiknya berani mengambil sikap untuk menentukan waktu pelasanaan kegitan sehingga bisa mengantisipasi kekurangan SDM saat kegitan berlangsung. Mengingat hal tersebut sudah dillakukan terus menerus selama dua tahun alangkah baiknya pihak sekolah mencoba alternatif lain ( trial dan eror) dengan menentukan tangal kegitan parenting diawal semester saat pertemuan orangtua sehingga baik orangtua maupun pihak sekolah bisa mempersiapkan dengan baik.

\section{DAFTAR PUSTAKA}

Anisah Basleman dan Syamsu Mappa (2011) Teori Belajar Orang Deasa. Bandung: Pt Remaja Posdakarya.

Sujana Djuju. (2008) Evaluasi program pendidikan luar sekolah untuk pendidikan non 
Diklus: Jurnal Pendidikan Luar Sekolah, 1(1), Maret 2017 - 51

Kholisatul Nurjanah

formal dan pengembangan

sumberdaya manusia. Bandung:

PT Remaja

Rosdakarya

Suprijanto. (2007). Pendidikan Orang Dewasa Dari Teori Hingga Aplikasi. Jakarta: Pt Bumi Aksara.

Suprijanto. (2011). Pendidikan Oran

Dewasa Kota Penerbit.

Yasin Musthofa. (2007). Eq Untuk Anak

Usia Dini Dalam Pendidikan Islam.

Sketsa. 